\title{
Migration routes and non-breeding areas of Common Terns Sterna hirundo from the Azores
}

\begin{tabular}{|c|c|}
\hline Journal: & Emu - Austral Ornithology \\
\hline Manuscript ID: & MU13112.R2 \\
\hline Manuscript Type: & Research Paper \\
\hline Date Submitted by the Author: & $\mathrm{n} / \mathrm{a}$ \\
\hline Complete List of Authors: & $\begin{array}{l}\text { Neves, Verónica; Centre of IMAR of the University of the Azores \& LARSyS } \\
\text { Associated Laboratory, Department of Oceanography and Fisheries (DOP) } \\
\text { Nava, Cristina; Centre of IMAR of the University of the Azores \& LARSyS } \\
\text { Associated Laboratory, Department of Oceanography and Fisheries (DOP) } \\
\text { Cormons, Matt } \\
\text { Bremer, Esteban; Fundación Vida Silvestre Argentina, Departamento de } \\
\text { Conservacion } \\
\text { Castresana, Gabriel; Reserva Natural Bahía Samborombón, } \\
\text { Lima, Pedro; Universidade Federal da Bahía, } \\
\text { Junior, Severino; Universidade Federal Rural de Pernambuco, } \\
\text { Phillips, Richard; British Antarctic Survey, Natural Environment Research } \\
\text { Council } \\
\text { Magalhães, Maria; Centre of IMAR of the University of the Azores \& LARSyS } \\
\text { Associated Laboratory, Department of Oceanography and Fisheries (DOP) } \\
\text { Santos, Ricardo; Centre of IMAR of the University of the Azores \& LARSyS } \\
\text { Associated Laboratory, Department of Oceanography and Fisheries (DOP) }\end{array}$ \\
\hline Keyword: & Atlantic Ocean, migration, seabirds, movement \\
\hline
\end{tabular}




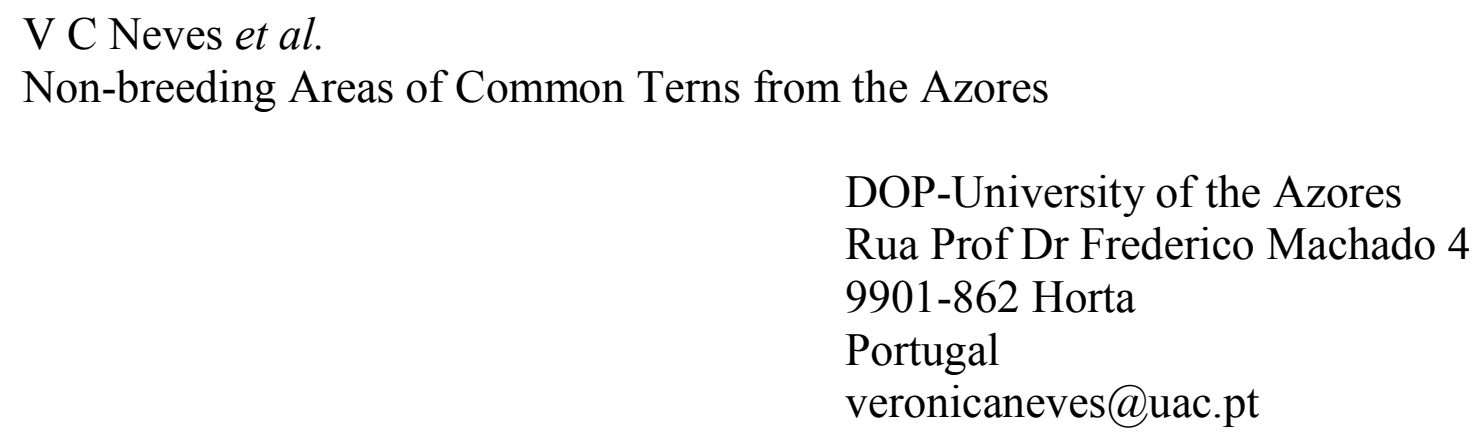

Migration routes and non-breeding areas of Common Terns Sterna hirundo

\section{1 from the Azores}

Verónica C. Neves ${ }^{\mathrm{A}, \mathrm{H}}$, Cristina P. Nava ${ }^{\mathrm{A}}$, Matt Cormons $^{\mathrm{B}}$, Esteban Bremer $^{\mathrm{C}}$, Gabriel

14 Castresana $^{\mathrm{D}}$, Pedro Lima ${ }^{\mathrm{E}}$, Severino M. Azevedo Junior ${ }^{\mathrm{F}}$, Richard A. Phillips ${ }^{\mathrm{G}}$, Maria C.

15 Magalhães $^{\mathrm{A}}$ and Ricardo S. Santos ${ }^{\mathrm{A}}$

16

${ }^{\text {A }}$ Centre of IMAR of the University of the Azores, Department of Oceanography and Fisheries (DOP) \& LARSyS Associated Laboratory, Rua Prof. Dr Frederico Machado 4, PT9901-862 Horta, Azores, Portugal

B 26201 Dennis Road, Parksley, Virginia, 23421, USA

${ }^{\mathrm{C}}$ Fundación Vida Silvestre Argentina, Departamento de Conservacion, Defensa $2516 \mathrm{~K}$, (1065), Ciudad Autonoma de Buenos Aires, Argentina

${ }^{D}$ Reserva Natural Bahía Samborombón, Organismo Provincial para el Desarrollo Sostenible, Buenos Aires, Argentina.

${ }^{\text {E } U n i v e r s i d a d e ~ F e d e r a l ~ d a ~ B a h i ́ a, ~ E S C M E V, ~ U F B A, ~ R u a ~ A d e m a r ~ d e ~ B a r r o s, ~} 500$ - Ondina Salvador - Ba CEP: 40170-110, Brazil

${ }^{\mathrm{F}}$ Universidade Federal Rural de Pernambuco, Departamento de Biologia, Laboratório de Ornitologia, 52171-900 - Recife, Brazil

${ }^{\mathrm{G}}$ British Antarctic Survey, Natural Environment Research Council, High Cross, Madingley Road, Cambridge CB3 0ET, UK

${ }^{\mathrm{H}}$ Corresponding author. Email: neves_veronica@yahoo.com 
34 Abstract. Here we report migration routes and non-breeding areas of Common Terns (Sterna

35 hirundo) from the Azores archipelago, based on ring recoveries (including live and dead

36 birds) and tracking using geolocators (global location-sensing or GLS loggers). To date, there

37 have been 55 transatlantic ring recoveries of Common Terns from the Azorean population -

38 six from Argentina and 49 from Brazil - reported over 15 different years. The three tracked

39 birds migrated southwards in different months (August, September and November), but were

40 more synchronous on the northbound migration, which in all cases began in April. The birds

41 were tracked to three different areas along the South American coast; the male spent

42 November to April on the north Brazilian coast $\left(13^{\circ} \mathrm{N}-2^{\circ} \mathrm{S}\right)$, whereas the two females first

43 spent some time off northeast Brazil ( $4-16^{\circ} \mathrm{S}$; one for a week and the other for three months)

44 and then moved south to the coast off southeast Brazil, Uruguay and northern Argentina (24-

$\left.4539^{\circ} \mathrm{S}\right)$. Although the values need to be viewed with caution given our small sample size and

46 the errors associated with geolocation, the tracked terns potentially travelled up to c. 23,194

$47 \mathrm{~km}$ in total to-and-from the non-breeding grounds, representing an average of about 500

$48 \mathrm{~km} /$ day. With the exception of Belém (north Brazil) and Lagoa do Peixe (south Brazil), the

49 coastal areas used by the tracked birds coincided with concentrations of ring recoveries,

50 confirming their importance as non-breeding areas for birds from the Azores population.

52 Additional keywords: at-sea distribution, Argentina, Brazil, geolocation, ring recoveries, 53 nonbreeding season, Patagonian shelf.

54

55

56

57 


\section{Introduction}

60

61

62

63

64

65

66

67

68

69

Over the last two decades, our knowledge of seabird movements and distribution at sea has been greatly improved by tracking technologies (Burger and Shaffer 2008, Phillips et al. 2008). In particular, the miniaturization of light-level geolocators (global location sensing or GLS loggers) has provided unprecedented detail on the migration of smaller species such as terns (Egevang et al. 2010, Nisbet et al. 2011a, Fijn et al. 2013, McKnight et al. 2013, van der Winden et al. 2014).

Ring recoveries have shown previously that the North American populations of the Common Tern Sterna hirundo spend the non-breeding period along the South American coast (Hays et al. 1997, 1999), and recently, Nisbet et al. (2011a) used geolocators to track the migration of five birds from a breeding colony in Massachusetts. Analyses of ringing data suggest that Common Terns from the NW European population have a rather different strategy, spending the non-breeding along the West African coast (Wernham et al. 2002).

Ring recoveries of Azores breeders off Brazil and Argentina (Hays et al. 1999, Neves et al. 2002, Lima et al. 2005) indicate that at least some Common Terns from the Azores spend the nonbreeding season on the South American coast, suggesting they use the same areas as birds from North America; however, details of the route and other aspects of migration remain poorly known.

More information is needed to ensure protection at the non-breeding grounds of Common Terns from the Azores population, which is substantial (c. 3000 pairs; Neves 2011) and unusual in that the birds breed on remote, oceanic islands. Hence, the purpose of this study was to combine data from ring recoveries and geolocator tracks to determine the distribution, timing of migration, routes and non-breeding areas of birds from the Azorean population. 
84

85

86

87

\section{Methods}

\section{Ring recoveries}

Ring recovery data provide snapshots of distribution and can be a good complement to tracking data (e.g. Harris et al. 2010). We present details of all the ring recoveries available in the Portuguese Ringing Centre database; these include seven previously published ring recoveries (Hays et al. 1999, Neves et al. 2002, Lima et al. 2005). We use the term "recovery" to include both birds trapped and released, and birds found dead (these are distinguished in Tables S1 and S2). The recoveries were made over a period spanning almost two decades (1993-2013) by different organizations and individuals in Brazil and Argentina. In Brazil, Common Terns have been ringed by over 25 different ringers. Nevertheless, most recoveries of Azorean birds in Brazil were obtained through the ringing program coordinated by P. Lima on the northeast coast of Brazil. Coastal surveys were conducted beforehand, using a single-engine airplane, to identify the sites with higher concentration of terns.

Trapping and ringing activities took place in January to April, November and December, for 3 to 10 days a year, between 16:00h and 05:00h, using 20 mist nets $(12 \times 2.5 \mathrm{~m} ; 12 \mathrm{~mm}$ mesh) (Lima et al. 2005). In Argentina, terns have only been trapped at one location, Punta Rasa; trapping involved mist netting from 1993 until 2008, and use of cannon nets $\left(16^{*} 7 \mathrm{~m}\right)$ since 2010, in periods of 1-3 days in January to March, November and December each year. No tern ringing was conducted in Punta Rasa in 2009.

\section{Study area}

The nine islands of the Azores archipelago hold about 50 colonies of Common Tern. The tracking study was conducted at Praia islet $\left(39^{\circ} 03^{\prime} \mathrm{N}, 27^{\circ} 57^{\prime} \mathrm{W} ; 0.12 \mathrm{~km}^{2}\right)$, Graciosa island, Azores archipelago, between 7 and 15 June 2011, and 26 May and 19 June 2012. Praia islet provides breeding habitat for six seabird species including Common Terns and Roseate Terns 
109 (Sterna dougallii). In the mid-1990s, Praia islet benefited from a habitat restoration program

110 and tern numbers rose sharply, accounting for one third of the Azorean breeding population in

1112003 (Bried et al. 2009). Since then, the islet has remained an important site for terns,

112 including c. 350 Common Tern pairs in 2011 (Neves 2011). Praia islet is one of the few

113 Azorean colonies where a geolocator study could be conducted; the others are Vila islet (off

114 Santa Maria island) and Feno islet (off Terceira island). Unlike most others in the Azores,

115 these colonies are accessible, the nests are located in areas where birds can be trapped, and

116 they normally hold over 100 pairs. However, Vila islet has suffered from problems relating to

117 egg predation by European Starling (Sturnus vulgaris) (Neves et al. 2011), and rats Rattus

118 rattus can be a problem at Feno islet (Amaral et al. 2010). Therefore we decided to conduct

119 the study at Praia islet.

Geolocator deployment

122 We deployed a total of 29 geolocators (15 Mk10 and 14 Mk18; British Antarctic Survey,

123 Cambridge, UK) on adult breeding Common Terns captured using walk-in treadle traps set

124 over their nests. Birds were measured (wing length, tarsus, head and bill), weighed and ringed

125 (with a metal ring, and a darvic ring to which the geolocator was attached, on opposite legs).

126 A 50- $\mu$ l blood sample was collected from the tarsal vein, from which sex was later determined

127 genetically (Fridolfsson and Ellegren 1999). A few turns of self-amalgamating tape were

128 wrapped around the waist of the logger (without obscuring the light sensor), which was then

129 attached using Kevlar $^{\odot}$ thread to the darvic ring; the thread was then covered with a resin

130 (West System $_{\circledast}$ G/5 adhesive epoxy) to reduce the likelihood of breakage (see Fig. S1,

131 Supplementary Online Material). The total weight (darvic ring, geolocator and attachment)

132 was $1.7 \pm 0.3 \mathrm{~g}$, representing on average $1.2 \%$ of bird body mass, which is well below the load

133 threshold (3\%) beyond which adverse effects are more likely to occur (Kenward, 2001, 
134 Phillips et al. 2003). However, note that Nisbet et al. (2011a) reported serious injuries after a

135 few days in four of 14 birds fitted with loggers that represented $1.2 \%-1.6 \%$ of body mass.

136 From our visual observations, the birds in our study were doing well up to several days after

137 deployment. We equipped only one individual per pair to limit disturbance; their mates were

138 also marked with a metal and a white darvic ring so that they would be easy to spot the

139 following year. Upon recovery, the birds were weighed and the logger removed. The

140 geolocators were calibrated at a fixed location before and after deployment.

141

\section{Geolocator data analysis}

143 Light data were downloaded from the retrieved loggers and processed using BASTrak

144 software (British Antarctic Survey) to estimate the latitude from day length and longitude

145 from the time of local midday relative to Greenwich Mean Time. The geolocators measure

146 light values every minute and store the maximum reading (truncated at an arbitrary value of

147 64) at the end of every 10-min period. During processing, we used a light threshold of 20 and

148 an angle of elevation of the sun of $-3.5^{\circ}$, based on known positions obtained during

149 calibration of the loggers before and after deployment. During analysis, we excluded locations

150 derived from curves with apparent interruptions around sunset and sunrise, and also locations

151 around the spring and autumn equinoxes that were clearly inaccurate based on visual

152 examination. Outside the equinox periods, mean accuracy \pm SD has been estimated as $185 \pm$

$153114 \mathrm{~km}$ at c. $50-60^{\circ} \mathrm{S}$ (Phillips et al. 2004), but for terns at lower latitudes, Nisbet et al.

154 (2011a) estimated the accuracy of latitude and longitude to be around $340 \mathrm{~km}$ and $105 \mathrm{~km}$,

155 respectively. Bird locations at sea were stored in a WGS84 datum and examined using

156 ArcView GIS 10.1 (ESRI). Local movements within the non-breeding sites were not included

157 in the calculation of overall migration distances. For each individual, the dates of departure

158 and return to the breeding area were determined visually: departure date was considered to be

159 the first day when the bird's location was outside the cluster of positions of the previous days 
160 that corresponded to the breeding area, followed by directed movement away from this area;

161 and arrival date was considered to be the first day the bird returned to the breeding region,

162 preceded by a directed movement towards that area. Non-breeding areas were considered to

163 be the areas used by the birds after leaving the Azores region. We estimated the total distance

164 travelled during the northbound and southbound migrations as the sum of the great-circle

165 distances between the mean of the two daily positions, to allow comparison with previous

166 studies (Egevang et al. 2010, Fijn et al. 2013, van der Winden et al. 2014). Mean travel speed

167 during migrations is defined as the mean of daily distance travelled during those periods. As

168 mentioned above, there is an error associated with both latitude and longitude estimation and

169 so these values are indicative only, and biased upwards. The loggers also recorded saltwater

170 immersion (wet/dry) at 3-s intervals using 2 electrodes, and stored the number of positive

171 tests as a value from 0 (continuously dry) to 200 (continuously wet) at the end of each 10-min

172 period. Saltwater immersion data were combined with the light data recorded by the loggers

173 to determine the amount of time and the proportions of time spent bathing/resting at the sea

174 surface during daylight and darkness. These data were processed using customised functions

175 in R (R Development Core Team, 2008). Wet-dry data do not accurately reflect time spent

176 foraging, as terns pick food items from the sea surface and are usually submerged for less

177 than $3 \mathrm{sec}$.

178

179 Results

180 Ring recoveries

181 In the 1990s, Common Terns originally ringed in the Azores were recovered along the South

182 American coast (Hays et al. 1999, Lima et al. 2005, Neves et al. 2002), demonstrating for the

183 first time a regular transatlantic movement. In 1993, Severino Azevedo Junior netted the first

184 Azorean Common Tern to be found in Brazil at Coroa de Avião on the northeast coast, and 
185 there have been dozens of subsequent recoveries. Common Terns from the Azores have now

186 been recovered at seven sites on the South American coast between $4^{\circ} 57^{\prime} \mathrm{N}$ and $36^{\circ} 18^{\prime} \mathrm{N}$ (see

187 Tables S1 and S2, supplementary online material). Additionally, a Common Tern ringed in

188 Punta Rasa (Argentina) with an orange plastic ring was resighted in the Azores (Lajes do

189 Pico) in August 2011 (see Fig S2, supplementary online material). Of the 55 recoveries, 36

190 were of birds of known age (range: 1-13 years); the most common age classes were juveniles

191 (birds $<1$ year old) $(28 \%$ of the total) and 5-year olds (11\%); all other age classes represented

$1928 \%$ or less of the total. About $95 \%$ of the recoveries were made between November and

193 February; the latest recovery date in any year was 21 May, by which time breeding is well

194 underway in the Azores (this recovery was of a juvenile). There are no demographic studies

195 of terns in the Azores, but ringing studies at three of the main Common Tern breeding sites

196 (Praia, Vila and Feno islets) indicate that first- and second-summer birds very rarely visit

197 colonies (V Neves, personal observation). Thus, it is possible that immature terns may not

198 return to the Azores until ready to breed around the age of three.

199 To date, a total of 7834 Common Terns have been ringed at nine principal locations in

200 Brazil (see Table 1). In five of these locations, Azorean terns have not been recovered,

201 probably due to the low number of terns ringed or the timing of ringing. Even though $39 \%$ of

202 the terns ringed in Brazil were ringed at Lagoa do Peixe, no Azorean birds has ever been

203 recovered there. This is probably due to timing; the bulk of ringing at this site has been in

204 April and November, months in which there are only two recoveries of Azorean birds in

205 Brazil. Table 2 shows the number of birds ringed per month in Mangue Seco and Caixa

206 Prego, as well as the number of recoveries from the Azores. Over 90\% of the Mangue Seco

207 recoveries occurred in December, January and February, and the recovery rates over those

208 months in relation to ringing effort are disproportionately high. In addition, although many

209 birds are ringed there in November, there is only one Azorean bird recovered in that month. 
210 Together, these results suggest that Azorean birds mainly use Mangue Seco in December to

211 February. Similarly, at Caixa Prego, birds were only recovered in January and February;

212 however, that may be an artifact of ringing effort, as fewer birds were ringed in other months.

213 Between 1993 and 2013 a total of 4414 Common Terns were ringed at Punta Rasa

214 (Argentina) and in the same period a total of six birds from the Azores were recovered at that 215 location, representing $0.14 \%$ of ringing effort. There is currently no Ringing Centre in

216 Argentina and we couldn't obtain detailed data regarding number of birds ringed in each

217 month. However, given the small number of recoveries of Azorean birds in Argentina it

218 would be difficult to draw any conclusions of seasonal occurrence from ringing effort and

219 recovery rate.

220

221

\section{Tracking}

222

In 2012, we observed a minimum of 10 birds (35\%) that had been fitted with loggers in 2011; however, we recovered geolocators from only three individuals $(10 \%$; two females and one male), including one bird that had moved island (see below). The low recovery rate was due to egg predation by the European starling (Sturnus vulgaris), which resulted in nest desertion by the terns. When we first visited the islet in late May 2012, we found that considerable depredation had occurred and the number of eggs/nests relative to the number of terns present was low. On another visit in June, we found that predation was still intense. The nests of at least 4 birds with geolocators were depredated before we could trap the adult. The two Mk18 loggers recovered from females were in good condition upon recovery, but the Mk10 logger

231 from the male had failed due to water ingress; fortunately, the extracted data indicated that it

232 had stopped working only a few days earlier so locations were available for most of the 233 deployment period. The three birds that were retrapped were all nesting with the same mate as

234 in 2011. We visited Praia islet again in 2013, between 19 June and 1 July, but located only 
235 one bird with a geolocator in an area about $200 \mathrm{~m}$ away from its nest in 2011 . The bird had a

236 single egg that was depredated within 24-h of discovery and therefore we were unable to

237 recover the geolocator.

238 One female (B017), was recaptured on 28 May 2012 at a nest with three eggs, and

239 weighed $128 \mathrm{~g}$ (34 g less than 2011). The second female, B015, was recaptured on 11 June

2402012 on a nest with two eggs and weighed $142 \mathrm{~g}$ (the same as 2011). The male (21970) was

241 recaptured on 19 June 2012 on a nest with two eggs (one of them pipping) and weighed $130 \mathrm{~g}$

242 (3 g less than 2011). The decrease in weight (by 20\%) of bird B017 between years was similar

243 to that $(30 \mathrm{~g} ; 18 \%)$ of the unequipped mate of an equipped bird at another nest, so does not

244 necessarily represent an adverse effect of the device.

245 The two females were recaptured on Praia islet where they were originally marked in

246 2011, but the male had moved $80 \mathrm{~km}$ to a different colony: Feno islet, off the island of

247 Terceira. It is possible that other birds fitted with loggers had emigrated from Praia islet due

248 to the high level of breeding failure caused by the starlings; if so, this would have

249 substantially reduced the resighting rate as there are over 50 Common Tern colonies on the

250 nine islands of the Azores.

251 Birds departed the breeding grounds between 24 August and 10 November (Table 3).

252 Female B017 left Praia islet on 24 August, flew southwards across the Atlantic for seven days

253 and arrived at NE Brazil by 31 August. She spent the first week of September in this area

254 (area B, see Fig 1 and Table 4) and then quickly moved to southern Brazil (area D, see Fig 1

255 and Table 4); on 8 September she was at $9^{\circ} \mathrm{S}, 36^{\circ} \mathrm{W}$ (area B, see Fig 1 and Table 4) and by 10

256 September was at $21^{\circ} \mathrm{S}, 41^{\circ} \mathrm{W}$, having flown c. $1500 \mathrm{~km}$ in just two days. Due to proximity to

257 the equinox, there are no reliable locations from 11 September to 3 October for bird B017 in

258 area D (see Fig 1 and Table 4); however, based on the available longitudes, the bird was

259 moving south along the Brazilian coastline. This individual then spent $>3$ months in area D 
260 (see Fig 1 and Table 4) and by early January moved slightly south to an area off southeast

261 Brazil, Uruguay, and northeast Argentina, around the mouth of Rio de la Plata, where it

262 remained until 10 March (area F, see Fig 1 and Table 4). The locations became unreliable due

263 to the spring equinox until 12 April, when the bird was at $11^{\circ} 21^{\prime} \mathrm{N}, 51^{\circ} 43^{\prime} \mathrm{W}(663 \mathrm{~km}$ off the

264 north coast of Brazil; see Fig 1), already on its northbound migration. By 20 April, B017 was

265 back at the Azores archipelago, having travelled c. $475 \mathrm{~km} /$ day on average during the period

266 12-20 April.

267 Female B015 used non-breeding areas similar to female B017, but the timing differed.

268 The southbound migration started later, in mid-late September, and by 4 October the bird was

269 already in area B (see Fig 1 and Table 4) where it remained until 11 November. For several

270 weeks, the movements of B015 were restricted to a smaller area (area C; see Fig 1 and Table

271 4), before the bird moved between 3 and 7 January to southern Brazil (area E, see Fig 1 and

272 Table 4) where it remained until 10 March. We have no accurate location data between 11

273 March and 10 April, by which time B015 was already on its northbound migration (1165 km

274 off the north coast of Brazil, at $9^{\circ} 04^{\prime} \mathrm{N}, 43^{\circ} 03^{\prime} \mathrm{W}$; see Fig 1). By 18 April, the bird was back

275 at the Azores archipelago, having travelled c. $524 \mathrm{~km} /$ day on average during the period 10-18

276 April.

277 The male (21970) started its southward migration around 10 November (see Table 3).

278 Its movements contrasted with those of the females; the bird did not reach the non-breeding

279 grounds until 18 November (area A, see Fig 1 and Table 4) and apparently remained in the

280 same area until late April-early May, before starting the northward migration (but note that

281 there are no reliable location data between 23 February and 9 April because of proximity to

282 the equinox). This bird had returned to the Azores by 30 May.

283 All tracked birds spent the non-breeding period (corresponding to the Northern

284 Hemisphere winter) near river mouths or lagoons; area A (Belém) includes the mouth of Rio 
Amazonas, areas B and C include the mouth of Rio São Francisco and Rio Real and areas D-F include the mouth of Rio de la Plata and Lagoa do Peixe, a large lagoon in southern Brazil. Estimates of travel speeds (above and on Table 3) have to be viewed with caution due to the uncertainties inherent in the geolocation method; thus the values presented are indicative only and biased upwards. The same is true for the estimates of distances travelled during southbound and northbound migrations. Our results indicate that birds could travel up to $11,597 \mathrm{~km}$ between the non-breeding areas and the Azores, however, the shortest, direct route is only about $9,000 \mathrm{~km}$. The real value will probably lie in between as it is unlikely that birds will always be able to fly the shortest route due to weather (especially wind) conditions, diversions to feed, possible navigational errors etc.

295

296

\section{Activity (immersion) data}

297 During the breeding, post-breeding and pre-breeding periods, the tracked Common Terns

298 spent short amounts of time sitting on the sea surface during daylight (0.1-1.6 min.day ${ }^{-1}$ on

299 average), but up to an hour or more on the water during darkness (5.9-74.6 min.day ${ }^{-1}$ on

300 average) (see Table 5). During the autumn and spring migration, the amount of time that birds

301 rested on the water approximately doubled, but there was considerable variation between days

302 and individuals. When crossing the Atlantic during the autumn and spring migration, terns

303 were very active, never resting for $>3 \mathrm{~h}$ a night, and on some nights, even flying non-stop.

304 Time spent on the sea surface was highest during the non-breeding period (7.6-134.8 min.day ${ }^{-}$

$305{ }^{1}$ on average), with birds occasionally resting on the water for up to a maximum of $10 \mathrm{~h}$ during 306 daylight and $6 \mathrm{~h}$ during darkness (see Table 5).

307

308

309 


\section{Discussion}

311 Our study, which is only the second published tracking dataset for this species during the non-

312 breeding period, recorded considerable individual variation in the timing of migration and 313 non-breeding areas used by Common Terns from the Azores archipelago. In particular, the

314 two females in our study started the autumn migration over a month earlier than the male.

315 Although this result should be viewed with caution given the small sample, it suggests that 316 some of the variability in timing of migration might be sex-related, particularly as a similar 317 pattern was evident in Common Terns tracked from a North American colony (Nisbet et al.

318 2011a, b), although not in Arctic Terns (Sterna paradisaea) from Greenland or The

319 Netherlands (Egevang et al. 2010, Fijn et al. 2013). Nisbet et al. (2011b) suggested that the

320 differences in departure dates were because males perform more post-fledging care than

321 females, and so remain for longer at the breeding grounds. Timing of migration may also be

322 responsive to local environmental conditions, as Common Terns from the Azores departed

323 from their breeding grounds from one week to three months later than their American

324 conspecifics, but returned earlier at the start of the following season (Nisbet et al. 2011a, this

325 study). The tracked birds from the Azores also travelled faster than US birds, probably

326 because they had to cross the Atlantic Ocean, whereas the terns from the US migrated in short

327 steps, stopping and feeding along the coast.

328 Following their arrival off South America, the tracked Common Terns did not settle in 329 a restricted area but rather remained mobile, and were dispersed over a wide region. This is

330 the same region used by non-breeding Common Terns from North America (Nisbet et al.

331 2011a), and in which all the ring recoveries of non-breeding birds from the Azores have been

332 reported (Hays et al. 1999, Neves et al. 2002, this study). Hays et al. (1999) suggested that

333 Common Terns from the Azores congregated at Mangue Seco (Area 3) during the non-

334 breeding season, a hypothesis corroborated by the large number of subsequent recoveries and 
335 by our tracking data. Mangue Seco seems to be particularly important for Azorean terns

336 during the months of December and January. In addition, we identified two other important

337 non-breeding areas for Azores Common Terns on the Brazilian coast; Belém in the north, and

338 Lagoa do Peixe in the southeast, two areas previously known to be important for other tern

339 populations. Hays et al. (1997) also suggested that Punta Rasa in Argentina was one of the

340 most important non-breeding areas in South America for the North American populations of

341 Common Terns. Despite the small sample size, our tracking data, as well as the six ring

342 recoveries and the resighting, suggest that this area is important for the Azorean population as

343 well. It is important to note that birds are not restricted just to this site but use a large area that

344 includes Lagoa do Peixe in southern Brazil.

345 All tracked individuals spent the non-breeding period in very productive waters. The

346 male used coastal waters at the Amazon river mouth, a productive region where there are

347 extensive marine fisheries (Oliveira et al. 2007). The two females spent time on the northern

348 Patagonian Shelf (continental shelf extending from Uruguay to the Strait of Magellan), which

349 is important for numerous other seabird species (Croxall and Good 2002, Phillips et al. 2005,

350 Falabella et al. 2009, Guilford et al. 2009, Catry et al. 2011), and also an important area for

351 commercial fisheries (e.g. Csirke 1987).

352 None of the tracked birds travelled to the West African coast, which is the non-

353 breeding area of the large breeding populations of Common Terns in continental Europe and

354 the UK (Wernham et al. 2002). Common Terns from the Azores represent the only population

355 of a non-pelagic bird species that breeds in Europe and spends the Northern Hemisphere

356 winter in South America. Szczys et al. (2012) found that Common Terns from the Azores

357 were genetically more similar to those from North America than those from mainland Europe.

358 This matches with the migration patterns of the different populations. There have been

359 considerably fewer recoveries of Roseate Terns from the Azores, but they indicate that birds 
360 of this species, contrary to the results for the Common Tern, may spend the non-breeding

361 period on either side of the Atlantic. To date there have been 12 recoveries of Roseate Terns

362 from the Azores (Hays et al. 2002; Neves, unpublished data); four in Brazil (in the months of

363 November, January, February and March) and eight in Africa (in the months of October,

364 November, January, March, April and June).

365 Our tracked females had arrived back at the Azores in spring before their American

366 counterparts had even left the Brazilian coast (Nisbet et al. 2011a). A pattern of relatively

367 slow post-breeding migration, and a much more rapid migration back to the colony in the

368 spring, has been found for many bird species including terns (Egevang et al. 2010, Nisbet et

369 al. 2011a). Our data seems to indicate that birds from the Azores do not fly faster on the

370 return journey, but more tracking studies are needed given our small sample size. Overall, the

371 tracked birds fly on a more or less direct bearing to the non-breeding grounds, without any

372 apparent need to stop for more than a few hours to refuel during the journey. On the return

373 migration in the spring, birds took a route that was to the west of the southward journey, and

374 again made no stop-over, probably because the trip from the Brazilian coast to the Azores is

375 relatively short (c. 8 days at c. $500 \mathrm{~km} /$ day).

376 The immersion data show that, overall, Common Terns from the Azores spend less

377 time sitting in the water during the day, and more time in the water during the night than their

378 North American counterparts, whereas their activity patterns are similar during the non-

379 breeding period (Nisbet et al. 2011a). During the pre-breeding, breeding and post-breeding

380 periods, Common Terns from the Azores spent much longer in the water (presumably

381 resting), during darkness than daylight. While migrating, the tracked terns rested less during

382 the day (especially during the spring migration) than the North American terns (Nisbet et al.

383 2011a), and spent broadly similar periods sitting in the water during darkness. 
385 Common Terns during the non-breeding period. The majority of these offshore areas have

386 been identified as marine Important Bird Areas, but some have not yet been granted formal

387 and effective protection (BirdLife International 2012). In the past, adult Common and Roseate

388 terns have been trapped deliberately by locals to remove their rings in certain places on the

389 north and east coasts of Brazil. Villagers from Quixaba on the north coast no longer take rings

390 and are working to help conserve the terns (Hays 2009), but trapping for rings could still take

391 place elsewhere. In Punta Rasa (Argentina), tourists might cause some disturbance to terns

392 roosting on coastal beaches (Castresana, pers. obs.), but the severity of these impacts remains

393 to be evaluated.

394

\section{Acknowledgments}

396 We are grateful to R. Oliveira and L. Aguiar for transport to Praia islet and to Alexandre and

397 Rita (Octopus) for transport to Feno islet. We also thank L. F. Correia for help with fieldwork

398 in Feno Islet, R. Medeiros for help with Figure 1, and J. Bried for help with lab procedures for

399 sex determination. We thank J. di Costanzo for suggestions on geolocator deployment and for

400 help with archived ring recovery data. We are also very grateful to Janet Silk for providing

401 the $\mathrm{R}$ code to analyse the immersion data. Thanks to Biotrack for extracting data from the

402 failed logger. Thanks also to P. Figueiredo from CEMPA for help and clarification with the

403 ring recoveries and to M. Souza from CEMAVE for help with ringing data from Brazil. We

404 are also very grateful to all the many ringers of $S$. hirundo in Brazil who allowed us to use

405 their records and to Ramsés Peréz for allowing us to use his picture (Fig S2). Finally we thank

406 J. Bried, H. Hays, G. Cormons and anonymous referees for many useful comments that have

407 helped improve the manuscript. Fieldwork was conducted under permits $n^{\circ} 43 / 2011$ and

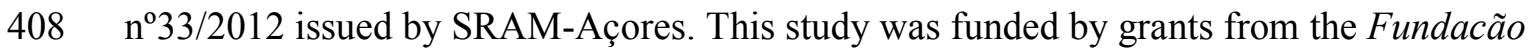


409

410

411

412

413

414

415

416

417

418

419

420

421

422

423

424

425

426

427

428

430

431

432

para a Ciência e a Tecnologia (SFRH/BPD/26657/2006 \& SFRH/BPD/88914/2012) and also

received support from MoniAves (2009-2012, SRAM) coordinated by R. S. Santos. IMAR-

DOP/UAç is funded by FCT and DRCT Azores (Research Unit No 531 and Associate

Laboratory No 9-ISR-Lisbon).

\section{References}

Amaral, J., Almeida, S., Sequeira, M. \& Neves, V. C. (2010). Black rat Rattus rattus eradication by trapping allows recovery of breeding roseate tern Sterna dougallii and common tern S. hirundo populations on Feno islet, the Azores, Portugal. Conservation Evidence 7:16-20.

Birdlife International (2012). The e-Atlas of Marine Important Bird Areas. http://maps.birdlife.org/marineIBAs/default.html

Bried J., Magalhães, M. C., Bolton, M., Neves, V. C., Bell, E., Pereira, J. C., Aguiar, L., Monteiro, L. R., and Santos, R. S. (2009). Seabird habitat restoration on Praia Islet, Azores archipelago. Ecological Restoration 27(1), 27-36.

Burger, A. E., and Shaffer, S. A. (2008). Application of tracking and data-logging technology in research and conservation of seabirds. Auk 125, 253-264.

Catry, P., Dias, M. P., Phillips, R. A., Granadeiro, J. P. (2011). Different Means to the Same End: Long-Distance Migrant Seabirds from Two Colonies Differ in Behaviour, Despite Common Wintering Grounds. PLoS ONE 6(10), e26079.

Croxall, J. P. and Good, A. G. (2002). Importance of Patagonian shelf for top predators. Aquatic Conservation Marine and Freshwater Ecosystems 12, 101-118.

Csirke, J. (1987). The Patagonian fishery resources and the offshore fisheries in the southwest Atlantic. FAO Fisheries Technical Paper 286. FAO: Rome. 
433 Egevang, C., Stenhouse, I. J., Phillips, R. A., Petersen, A., Fox, J. W., and Silk, J. R. D.

434 (2010). Tracking of Arctic Terns Sterna paradisaea reveals longest animal migration.

435 Proceedings of the National Academy of Science of the USA 107, 2078-2081.

436 Falabella, V., Campagna, C., and Croxall, J. (Eds). (2009). Atlas of the Patagonian Sea.

437 Species and Spaces. Buenos Aires, Wildlife Conservation Society and BirdLife

$438 \quad$ International.

439 Fijn, R. C., Hiemstra, D., Phillips, R. A., and Winden, J. (2013). Arctic Terns Sterna

440 paradisaea from The Netherlands migrate record distances across three oceans to Wilkes

441 land, East Antarctica. Ardea 101, 3-12.

442 Fridolfsson, A. K., and Ellegren, H. (1999). A simple and universal method for molecular

443 sexing of non-ratite birds. Journal of Avian Biology 30, 116-121.

444 Guilford, T. C., Meade, J., Willis, J., Phillips, R. A., Boyle, D., Roberts, S., Collett, M.,

445 Freeman, R., and Perrins, C. M. (2009). Migration and stopover in a small pelagic seabird,

446 the Manx Shearwater Puffinus puffinus: insights from machine learning. Proceedings of

447 the Royal Society B 276, 1215-1223.

448 Harris, M. P., Daunt, F., Newell, M., Phillips, R. A., and Wanless, S. (2010). Wintering

449 areas of adult Atlantic puffins Fratercula arctica from a North Sea colony as revealed by $450 \quad$ geolocation technology. Marine Biology 157, 827-836.

451 Hays, H. 2009. A Rosy Return. Natural History 118(10): 48.

452 Hays, H., Dicostanzo, J., Cormons, G., Zuquim Antas, P., Nascimento, J. L. X., Nascimento,

453 I. L. S., and Bremer, R. E. (1997). Recoveries of Roseate and Common Terns in South

$454 \quad$ America. Journal of Field Ornithology 68 (1), 79-90.

455 Hays, H., Lima, P., Monteiro, L., Dicostanzo, J., Cormons, G., Nisbet, I. C. T., Saliva, J. E.,

456 Spendelow, J. A., Burger, J., Pierce, J., and Gochfeld, M. (1999). A nonbreeding 

Ornithology 70(4), 455-464.

459

460

461

462

463

464

465

466

467

468

469

470

471

472

473

474

475

476

477

478

479

Hays, H., Neves, V. C., and Lima, P. (2002). Banded Roseate Terns from different continents trapped in the Azores. Journal of Field Ornithology 73(2): 180-184.

Kenward R. E. (2001). A manual for wildlife radio tagging. Academic Press, London.

Lima, P. Hays, H., Ferreira, Lima, R. C. F., Cormons, T., Cormons, G., DiCostanzo, J., and Santos, S. S. (2005). Recuperações de Sterna hirundo (Linnaeus, 1758) na Bahía, Brasil, entre 1995 e 2004. Revista Brasileira de Ornitologia 13, 177-179.

McKnight, A., Allyn, A. J., and Birons, D. (2013). 'Stepping stone’ pattern in Pacific Arctic tern migration reveals the importance of upwelling areas. Marine Ecology Progress Series 491, 253-264.

Neves, V. C. (2011). Azores Tern Census Report. University of the Azores, Department of Oceanography \& Fisheries. Arquivos do DOP, Série Estudos nº 1/2011.

Neves, V. C., Bremer, E., and Hays, H. (2002). Recovery in Punta Rasa, Argentina of Common Terns banded in the Azores Archipelago, North Atlantic. Waterbirds 25(4), 459461.

Neves V. C., Panagiotakopoulos S. and Ratcliffe N. (2011). Predation on roseate tern eggs by European starlings in the Azores. Arquipelago. Life and Marine Sciences 28: 15-23.

Nisbet, I. C. T., Mostello, C. S., Veit, R. R., Fox, J. W., and Afanasyev, V. (2011a). Migrations and winter quarters of five Common Terns tracked using geolocators. Waterbirds 34, 32-39.

Nisbet, I. C. T., Szczys, P., Mostello, C. S., and Fox, J. W. (2011b). Female Common Terns Sterna hirundo start autumn migration earlier than males. Seabird 24, 103-106. 
480 Oliveira, D. M, Frédou, T., and Lucena, F. (2007). A pesca no Estuário Amazônico: uma 481 análise uni e multivariada. Boletim do Museu Paraense Emílio Goeldi Ciências Naturais $482 \quad 2,11-21$.

483 Phillips, R. A., Xavier, J. C., and Croxall, J. P. (2003). Effects of satellite transmitters on $484 \quad$ albatrosses and petrels. Auk 120, 1082-1090.

485 Phillips, R. A., Silk, J. R. D., Croxall, J. P., Afanasyev, and D. R Briggs. (2004). Accuracy of 486 geolocation estimates for flying seabirds. Marine Ecology Progress Series 266, 265-272.

487 Phillips, R. A., Silk, J. R. D., Croxall, J. P., Afanasyev, V., and Bennett, V. J. (2005). Summer 488 distribution and migration of nonbreeding albatrosses: individual consistencies and 489 implications for conservation. Ecology 86, 2386-2396.

490 Phillips, R. A., Croxall, J. P., Silk, J. R. D., and Briggs, D. R. (2008). Foraging ecology of 491 albatrosses and petrels from South Georgia: two decades of insights from tracking 492 technologies. Aquatic Conservation: Marine and Freshwater Ecosystems 17, S6-S21.

493 R Development Core Team (2008). R: A language and environment for statistical computing.

494 R Foundation for Statistical Computing, Vienna, Austria. ISBN 3-900051-07-0, URL $495 \quad$ http://www.R-project.org.

496 Szczys, P., Nisbet, I.C.T., and Wingate, D. B. (2012). Conservation genetics of 497 the Common Tern (Sterna hirundo) in the North Atlantic region; implications 498 for the critically endangered population at Bermuda. Conservation Genetics $499 \quad \mathbf{1 3}, 1039-1043$.

500 Van Der Winden, J., Fijn, R. C., Van Horssen P, Gerritsen-Davidse, D. and Piersma, T T.

501 (2014). Idiosyncratic Migrations of Black Terns (Chlidonias niger): Diversity in Routes $502 \quad$ and Stopovers. Waterbirds 37(2), 162-174. 
503 Wernham, C. V., Toms, M. P., Marchant, J. H., Clark, J. A., Siriwardena, G. M., and Baillie,

504 S. R. (eds). (2002). 'The Migration Atlas: movements of the birds of Britain and Ireland'.

505 T. \& A.D. Poyser, London.

506

507 Figure caption:

508 Figure 1: Migration routes and non-breeding areas of three Common Terns (Sterna hirundo)

509 tracked from the Azores. Numbers as in Tables S1 and S2 (supplementary online material),

510 and letters as in Table 4. The star indicates the breeding colony. Tracks are incomplete for

511 birds that migrated in the periods around the equinoxes. The ellipses encompass all the

512 reliable positions obtained with geolocators during the non-breeding period.

513

514

515 Supplementary material Figures caption:

516 Figure S1: Leg of a Common Tern (Sterna hirundo) showing the Mk10 geolocator deployed 517 on a darvic ring.

518 Figure S2: Picture of a Common Tern (Sterna hirundo) resighted in Lajes do Pico (Azores)

519 in August 2011 and originally ringed in Punta Rasa (Argentina). C Ramsés Peréz. 


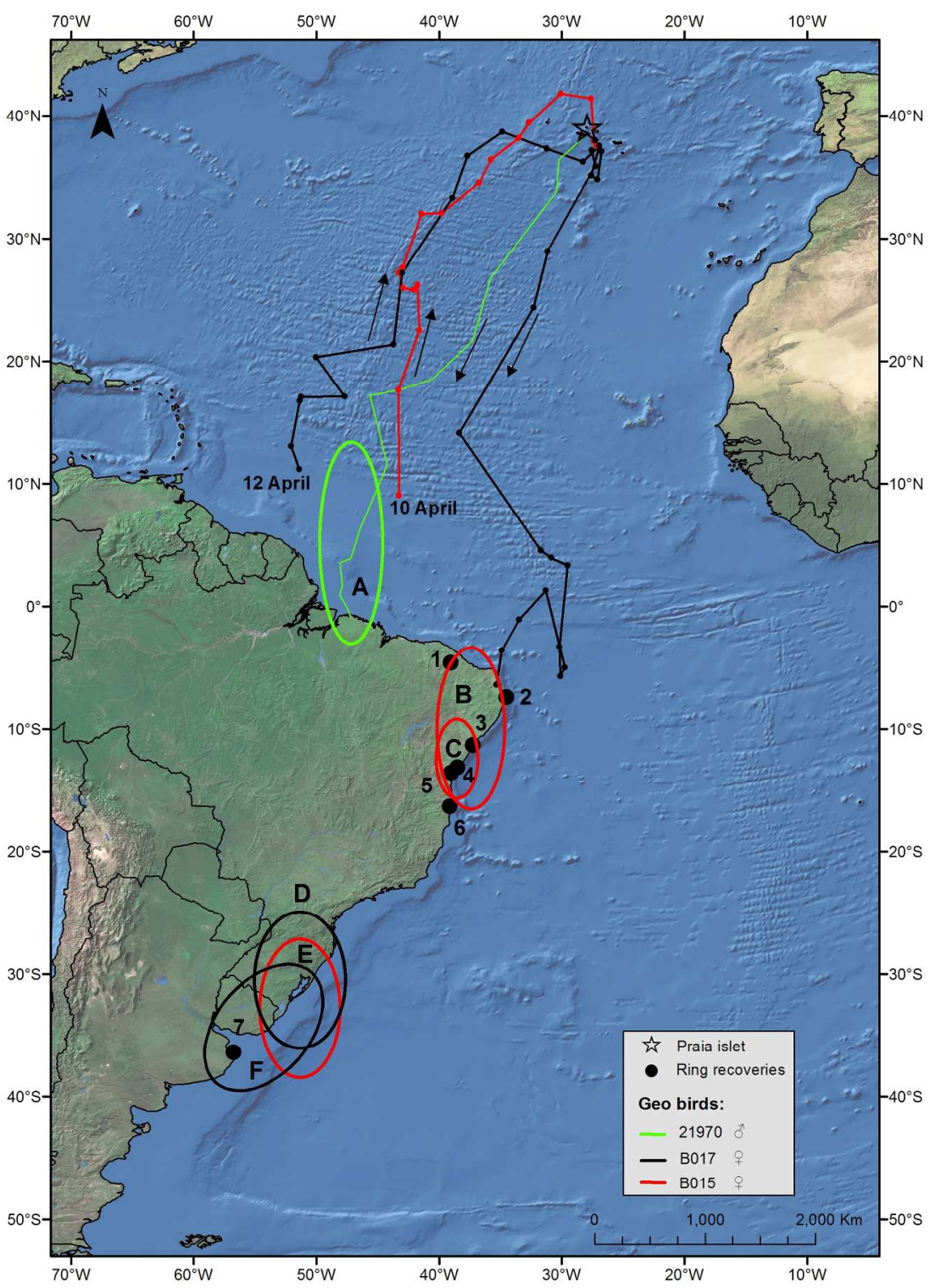

Figure 1: Migration routes and non-breeding areas of three Common Terns (Sterna hirundo) tracked from the Azores. Numbers as in Tables S1 and S2 (supplementary online material), and letters as in Table 2. The star indicates the breeding colony. Tracks are incomplete for birds that migrated in the periods around the equinoxes. The ellipses encompass all the reliable positions obtained with geolocators during the winter. $210 \times 296 \mathrm{~mm}(250 \times 250 \mathrm{DPI})$ 
Table 1: Timing of ringing and ringing effort for Sterna hirundo, and number of retraps of ringed birds from the Azores, at each ringing site in Brazil. Note that the total number of retraps from North American colonies is unknown, so it is not possible to express the percentage of all retraps that are of Azorean birds.

\begin{tabular}{|c|c|c|c|c|c|c|}
\hline Site & Latitude & Longitude & Ringing years & Ringing months & $\begin{array}{l}\text { Total ringing } \\
\text { effort (new } \\
\text { birds ringed) }\end{array}$ & $\begin{array}{c}\text { Total retraps of } \\
\text { Azorean rings ( } \% \text { of } \\
\text { total ringing effort) }\end{array}$ \\
\hline Algodoal/Salinas & $00^{\circ} 35-00^{\circ} 36^{\prime} \mathrm{S}$ & $47^{\circ} 22^{\prime}-47^{\circ} 34^{\prime} \mathrm{W}$ & 1983,1997 & April & 201 & 0 \\
\hline Campechá & $01^{\circ} 30^{\prime} \mathrm{S}$ & $44^{\circ} 45^{\prime} \mathrm{W}$ & 1994 & Nov & 2 & 0 \\
\hline Quixaba* & $04^{\circ} 57^{\prime} \mathrm{S}$ & $39^{\circ} 04^{\prime} \mathrm{W}$ & - & - & 0 & 2 \\
\hline Coroa de Avião & $07^{\circ} 40^{\prime}-08^{\circ} 03^{\prime} \mathrm{S}$ & $34^{\circ} 50^{\prime}-35^{\circ} 13^{\prime} \mathrm{W}$ & $\begin{array}{c}1987-94,1996-97,2001 \\
2005-07\end{array}$ & $\begin{array}{c}\text { Jan (3\%), Feb (3\%), April } \\
(6 \%) \text {, May }(3 \%), \text { June } \\
(4 \%), \text { July }(1 \%) \text {, Aug } \\
(6 \%) \text {, Sept }(8 \%), \text { Oct } \\
(32 \%), \text { Nov }(30 \%) \text { and } \\
\text { Dec }(4 \%)\end{array}$ & 79 & $1(1.3 \%)$ \\
\hline Mangue Seco & $11^{\circ} 27^{\prime}-12^{\circ} 40^{\prime} \mathrm{S}$ & $37^{\circ} 21^{\prime}-38^{\circ} 10^{\prime} \mathrm{W}$ & $\begin{array}{c}1986,1990,1995-97,2000 \\
2002-03,2005-09,2013\end{array}$ & $\begin{array}{c}\text { Jan }(28 \%), \text { Feb }(22 \%), \\
\text { March }(2 \%) \text { April }(<1 \%), \\
\text { Nov }(43 \%) \text { and Dec }(6 \%)\end{array}$ & 3932 & $31(0.8 \%)$ \\
\hline Caixa Prego & $13^{\circ} 08^{\prime}-13^{\circ} 53^{\prime} \mathrm{S}$ & $38^{\circ} 50^{\prime}-39^{\circ} 01^{\prime} \mathrm{W}$ & $2000-03,2007-08$ & $\begin{array}{c}\text { Jan }(21 \%), \text { Feb }(54 \%), \\
\text { April }(7 \%), \text { Nov }(6 \%) \text { and } \\
\text { Dec }(13 \%)\end{array}$ & 452 & $6(1.3 \%)$ \\
\hline Corumbal & $16^{\circ} 53^{\prime}-17^{\circ} 56^{\prime} \mathrm{S}$ & $38^{\circ} 39^{\prime}-39^{\circ} 06^{\prime} \mathrm{W}$ & $1995,1997,2003$ & $\begin{array}{c}\text { Feb }(72 \%) \text {, July }(26 \%) \\
\text { and Sept }(13 \%)\end{array}$ & 139 & $1(0.7)$ \\
\hline Ilha das Garças & $20^{\circ} 10^{\prime}-20^{\circ} 19^{\prime} \mathrm{S}$ & $40^{\circ} 10^{\prime}-40^{\circ} 19^{\prime} \mathrm{W}$ & $1995,2012-14$ & $\begin{array}{c}\text { Feb }(17 \%), \text { March }(33 \%), \\
\text { Set }(17 \%) \text {, Nov }(17 \%) \\
\text { and Dec }(17 \%)\end{array}$ & 6 & 0 \\
\hline Lagoa do Peixe & $31^{\circ} 17^{\prime} \mathrm{S}$ & $51^{\circ} 00^{\prime} \mathrm{W}$ & $\begin{array}{c}1985-89,1990-96,1998, \\
1999,2001-03,2010,2012-13\end{array}$ & $\begin{array}{l}\text { Jan }(2 \%), \text { March (1\%), } \\
\text { April }(67 \%) \text {, May }(2 \%) \\
\text { and Nov }(27 \%)\end{array}$ & 3022 & 0 \\
\hline $\begin{array}{l}\text { Museu } \\
\text { Oceanográfico }\end{array}$ & $32^{\circ} 01^{\prime} \mathrm{S}$ & $52^{\circ} 06^{\prime} \mathrm{W}$ & 2009 & March & 1 & 0 \\
\hline TOTAL & & & & & 7834 & $41(0.5 \%)$ \\
\hline
\end{tabular}

* No ringing was ever conducted at this location. The rings are from birds that were killed by fisherman. 
Table 2: Total number of Sterna hirundo ringed at Mangue Seco (MS, Brazil) and at Caixa Prego (CP, Brazil) in different months, and the number of retraps of ringed birds from the Azores.

\begin{tabular}{|l|c|c|c|c|}
\hline Month & \multicolumn{2}{|c|}{$\begin{array}{c}\text { Total ringing } \\
\text { effort (new birds } \\
\text { ringed) }\end{array}$} & \multicolumn{2}{c|}{$\begin{array}{c}\text { Total retraps of } \\
\text { Azorean rings (\% of } \\
\text { monthly ringing } \\
\text { effort) }\end{array}$} \\
\hline & MS & CP & MS & CP \\
\hline Jan & 1083 & 94 & $13(1.2 \%)$ & $2(2.1 \%)$ \\
\hline Feb & 859 & 243 & $5(0.7 \%)$ & $4(1.6 \%)$ \\
\hline March* & 62 & 0 & 1 & 0 \\
\hline April* & 1 & 30 & 1 & 0 \\
\hline Nov & 1698 & 25 & $1(0.1 \%)$ & 0 \\
\hline Dec & 229 & 60 & $10(4.8 \%)$ & 0 \\
\hline Total & 3932 & 452 & $31(0.8 \%)$ & $6(1.3 \%)$ \\
\hline
\end{tabular}

* Please note that the Azorean birds retrapped in March and April were not obtained during ringing activities but were found alive by fisherman and later released. Therefore we don't present the " $\%$ of monthly ringing effort" for those months. 
Table 3. Timing, distance covered and travel speed (mean with range in parentheses) during migration by three Common Terns Sterna hirundo tracked

from the Azores. Distance values in parentheses correspond to the shortest greatcircle routes to the South American coast and then to the non-breeding area, avoiding land.

\begin{tabular}{|c|c|c|c|}
\hline & B015 $(q)^{1}$ & B017 (q) & $21970\left(\delta^{\lambda}\right)^{1}$ \\
\hline $\begin{array}{l}\text { Start of southbound } \\
\text { migration }\end{array}$ & $\sim 14-30 \mathrm{Sep}$ & 24 Aug & $10 \mathrm{Nov}$ \\
\hline $\begin{array}{l}\text { Distance travelled on } \\
\text { southbound migration }\end{array}$ & - & $\begin{array}{l}10,686 \mathrm{~km} \\
(9,010 \mathrm{~km})\end{array}$ & $\begin{array}{c}4,901 \mathrm{~km} \\
(4,664 \mathrm{~km})\end{array}$ \\
\hline $\begin{array}{l}\text { Travel speed on } \\
\text { southbound migration }\end{array}$ & & $\begin{array}{c}454 \mathrm{~km} / \text { day }^{2} \\
(97-1104 \mathrm{~km} / \text { day })\end{array}$ & $\begin{array}{c}613 \mathrm{~km} / \text { day } \\
(43-1270 \mathrm{~km} / \text { day }) \\
\end{array}$ \\
\hline $\begin{array}{l}\text { Start of northbound } \\
\text { migration }\end{array}$ & $\sim 5 \mathrm{Apr}^{3}$ & $\sim 2 \mathrm{Apr}^{3}$ & $\begin{array}{c}\text { Between } 17 \text { Apr } \\
\text { and } 22 \text { May }\end{array}$ \\
\hline $\begin{array}{l}\text { Distance travelled on } \\
\text { northbound migration }\end{array}$ & $\begin{array}{c}\sim 10,470 \mathrm{~km} \\
(8,882 \mathrm{~km})\end{array}$ & $\begin{array}{c}\sim 11,597 \mathrm{~km} \\
(9,137 \mathrm{~km})\end{array}$ & - \\
\hline $\begin{array}{l}\text { Travel speed on } \\
\text { northbound migration }\end{array}$ & $\begin{array}{c}524 \mathrm{~km} / \text { day }^{4} \\
(184-1237 \mathrm{~km} / \text { day })\end{array}$ & $\begin{array}{c}475 \mathrm{~km} / \text { day }^{4} \\
(55-1290 \mathrm{~km} / \text { day }) \\
\end{array}$ & - \\
\hline $\begin{array}{l}\text { Arrival to breeding } \\
\text { grounds }\end{array}$ & 18 Apr & $20 \mathrm{Apr}$ & $\begin{array}{c}\text { Between } 24 \text { Apr } \\
\text { and } 30 \text { May }\end{array}$ \\
\hline
\end{tabular}

Note: The travel speed and distance values presented are indicative only and biased upwards.

${ }^{1}$ One of the migrations occurred around the equinox.

${ }^{2}$ Refers only to the first half of the migration from the Azores to northwest Brazil.

${ }^{3}$ Estimated from arrival date at the colony

${ }^{4}$ Refers only to the second half of the migration from north Brazil to the Azores. 
Table 4: Residency periods in the wintering areas of three Common Terns Sterna hirundo tracked from the Azores. Letter codes correspond to the areas in Fig. 1. Timing unknown in some cases because area used around the equinox period when no locations were available.

\begin{tabular}{|c|c|c|c|}
\hline Non-breeding areas & B015 (q) & B017 (q) & $21970\left(\circlearrowleft^{\lambda}\right)$ \\
\hline $\begin{array}{l}\text { A - Belém, Brazil } \\
\left(13^{\circ} \mathrm{N}-2^{\circ} \mathrm{S}, 45-49^{\circ} \mathrm{W}\right)\end{array}$ & - & - & $\begin{array}{c}18 \text { Nov }-16 \\
\text { Apr }\end{array}$ \\
\hline $\begin{array}{l}\text { B - NE corner, Brazil } \\
\left(4-16^{\circ} \mathrm{S}, 34-40^{\circ} \mathrm{W}\right)\end{array}$ & 4 Oct-11 Nov & 1-9 Sep & - \\
\hline $\begin{array}{l}\mathbf{C}-\text { Bahia, Brazil } \\
\left(6-15^{\circ} \mathrm{S}, 35-37^{\circ} \mathrm{W}\right)\end{array}$ & 12 Nov-3 Jan & - & - \\
\hline $\begin{array}{l}\text { D - Southern Brazil } 1 \\
\left(24-35^{\circ} \mathrm{S}, 49-53^{\circ} \mathrm{W}\right)\end{array}$ & - & $\begin{array}{l}\text { mid Sep to } \\
\text { Dec }\end{array}$ & - \\
\hline $\begin{array}{l}\mathbf{E}-\text { Southern Brazil } 2 \\
\left(26-38^{\circ} \mathrm{S}, 48-54^{\circ} \mathrm{W}\right)\end{array}$ & 7 Jan-10 Mar & - & - \\
\hline $\begin{array}{l}\text { F - Southern Brazil, } \\
\text { Uruguay \& northern } \\
\text { Argentina } \\
\left(28-39^{\circ} \mathrm{S}, 52-58^{\circ} \mathrm{W}\right)\end{array}$ & & $\begin{array}{l}\text { early Jan - } \\
10 \text { Mar }\end{array}$ & - \\
\hline
\end{tabular}


Table 5. Mean and range (min. - max.) of time spent sitting at the sea surface in daylight and darkness by three Common Terns Sterna hirundo, according to migration phase. The proportions of time spent on the water during daylight and darkness are given in parentheses.

\begin{tabular}{|c|c|c|c|c|}
\hline \multirow[b]{2}{*}{ Period } & \multicolumn{2}{|l|}{$D A Y$} & \multicolumn{2}{|l|}{ NIGHT } \\
\hline & Mean time on water $\left(\min \mathrm{d}^{-1}\right)$ & Range & Mean time on water $\left(\min \mathrm{d}^{-1}\right)$ & Range \\
\hline Breeding & $x_{1}$ & & & \\
\hline B015 & $0.2(<0.1 \%)$ & $0-1.1$ & $10.8(1.2 \%)$ & $0.4-80.7$ \\
\hline B017 & $1.1(0.2 \%)$ & $0-17.6$ & $25.0(2.7 \%)$ & $1.7-192.7$ \\
\hline 21970 & $0.3(<0.1 \%)$ & $0-1.2$ & $5.9(0.6 \%)$ & $0-20.0$ \\
\hline \multicolumn{5}{|c|}{ Post-breeding } \\
\hline B015 & $0.1(<0.1 \%)$ & $0-0.6$ & $13.1(1.6 \%)$ & $0.8-67.9$ \\
\hline B017 & $0.5(0.1 \%)$ & $0-3.3$ & $40.4(4.6 \%)$ & $5.7-220.2$ \\
\hline 21970 & $0.7(0.1 \%)$ & $0-15.1$ & $25.7(2.9 \%)$ & $0.9-248.2$ \\
\hline \multicolumn{5}{|c|}{ Autumn migration } \\
\hline B015 & $3.4(0.5 \%)$ & $0-63.0$ & $42.7(5.7 \%)$ & $1.4-143.3$ \\
\hline B017 & $25.8(3.7 \%)$ & $0-113.3$ & $78.9(9.9 \%)$ & $17.8-113.3$ \\
\hline 21970 & $4.9(0.6 \%)$ & $0-29.7$ & $76.0(10.1 \%)$ & $0.8-184.4$ \\
\hline \multicolumn{5}{|c|}{ Non-breeding } \\
\hline B015 & $7.6(1.2 \%)$ & $0-113.2$ & $123.8(15.6 \%)$ & $0.9-359.0$ \\
\hline B017 & $106.2(14.6 \%)$ & $0-623.6$ & $134.8(15.0 \%)$ & $0-430.7$ \\
\hline 21970 & $25.1(3.4 \%)$ & $0-177.6$ & $66.7(7.8 \%)$ & $0.6-311.6$ \\
\hline \multicolumn{5}{|c|}{ Spring migration } \\
\hline B015 & $0.4(0.1 \%)$ & $0-1.4$ & $71.2(8.8 \%)$ & $15.8-154.5$ \\
\hline B017 & $3.5(0.5 \%)$ & $0-9.9$ & $143.0(17.1 \%)$ & $0-276.8$ \\
\hline 21970 & - & - & - & - \\
\hline \multicolumn{5}{|l|}{ Pre-breeding } \\
\hline B015 & $1.6(0.3 \%)$ & $0-7.4$ & $74.6(8.8 \%)$ & $1.2-289.9$ \\
\hline B017 & $1.5(0.3 \%)$ & $0-7.4$ & $68.8(8.1 \%)$ & $1.4-164.8$ \\
\hline 21970 & - & - & - & - \\
\hline
\end{tabular}


Table S1: Recoveries in Brazil and Argentina of Common Terns Sterna hirundo ringed in the Azores as chicks or breeding adults. Recoveries ordered by increasing latitude. Number codes for the different sites correspond to those shown in Fig 2.

\begin{tabular}{|c|c|c|c|}
\hline Site & Ring & $\begin{array}{l}\text { Date } \\
\text { recapture }\end{array}$ & $\begin{array}{l}\text { Age (yrs, } \\
\text { months) }\end{array}$ \\
\hline \multirow{3}{*}{$\begin{array}{l}1 \text { - Brazil (Quixaba) } \\
\left(04^{\circ} 57^{\prime} \mathrm{S}, 39^{\circ} 04^{\prime} \mathrm{W}\right) \\
2 \text { - Brazil (Coroa de Avião) } \\
\left(07^{\circ} 40^{\prime} \mathrm{S}, 34^{\circ} 50^{\prime} \mathrm{W}\right)\end{array}$} & $\mathrm{G} 007153^{1}$ & $17 / 01 / 2002$ & 0 \\
\hline & G007228 ${ }^{1}$ & $17 / 01 / 2002$ & 0 \\
\hline & G002588 & $21 / 05 / 1993$ & 0 \\
\hline \multirow{31}{*}{$\begin{array}{c}3 \text { - Brazil (Mangue Seco) } \\
\left(11^{\circ} 27^{\prime} \mathrm{S}, 37^{\circ} 21^{\prime} \mathrm{W}\right)\end{array}$} & G006801 ${ }^{2}$ & 19/04/1998 & 0 \\
\hline & G006840 & $31 / 12 / 1997$ & 0 \\
\hline & G006873 & 27/12/1997 & 0 \\
\hline & G006925 & $23 / 02 / 1998$ & 0 \\
\hline & $\mathrm{G} 005070^{1,3}$ & $13 / 02 / 1996$ & 1 \\
\hline & G006702 & $23 / 02 / 1998$ & 1 \\
\hline & G011941 & $04 / 12 / 2007$ & 2 \\
\hline & $\mathrm{G} 011116$ & $27 / 01 / 2001$ & $>2$ \\
\hline & G011435 & $10 / 01 / 2002$ & $>2$ \\
\hline & $\mathrm{G} 002722^{4}$ & $30 / 12 / 1996$ & 3 \\
\hline & G011930 & $28 / 11 / 2008$ & 3 \\
\hline & G011084 & $11 / 01 / 2002$ & $>3$ \\
\hline & G003913 ${ }^{4}$ & $15 / 02 / 1996$ & 3 \\
\hline & G008671 & $11 / 01 / 2010$ & 3 \\
\hline & G011084 & $11 / 01 / 2002$ & $>3$ \\
\hline & & $26 / 01 / 2003$ & $>4$ \\
\hline & G006896 & $09 / 01 / 2002$ & 4 \\
\hline & G010738 & $04 / 12 / 2007$ & 4 \\
\hline & G007343 & $04 / 12 / 2007$ & 5 \\
\hline & G008769 & $11 / 01 / 2010$ & 5 \\
\hline & G002998 ${ }^{1}$ & 28/12/1997 & $>5$ \\
\hline & G002318 & $29 / 12 / 1996$ & 6 \\
\hline & G006527 & $27 / 01 / 2003$ & 6 \\
\hline & G011712 & $04 / 12 / 2007$ & $>7$ \\
\hline & G002587 & $27 / 01 / 2001$ & 8 \\
\hline & G003558 & $08 / 02 / 2000$ & 8 \\
\hline & G006874 & $04 / 12 / 2007$ & 10 \\
\hline & G002667 & $27 / 01 / 2003$ & 11 \\
\hline & $\mathrm{G} 002505^{2}$ & $01 / 03 / 2002$ & 11 \\
\hline & G003130 & $11 / 01 / 2002$ & 12 \\
\hline & G005493 & $26 / 01 / 2003$ & 12 \\
\hline \multirow{6}{*}{$\begin{array}{c}4 \& 5 \text { - Brazil (Caixa Prego) } \\
\left(13^{\circ} 08^{\prime}-13^{\circ} 53^{\prime} \mathrm{S}\right. \\
\left.38^{\circ} 50^{\prime}-39^{\circ} 01^{\prime} \mathrm{W}\right)\end{array}$} & G007311 & $04 / 02 / 2003$ & 0 \\
\hline & G007332 & $04 / 02 / 2003$ & 0 \\
\hline & G007239 & $26 / 01 / 2002$ & 0 \\
\hline & G011698 & $24 / 01 / 2002$ & $>2$ \\
\hline & G006590 & $05 / 02 / 2003$ & $>6$ \\
\hline & G002527 & $04 / 02 / 2003$ & 12 \\
\hline $\begin{array}{r}6-\text { Brazil (Corumbal) } \\
\left(16^{\circ} 53^{\prime} \mathrm{S}, 39^{\circ} 06^{\prime} \mathrm{W}\right)\end{array}$ & G006778 & $02 / 02 / 2003$ & 5 \\
\hline \multirow{6}{*}{$\begin{array}{l}7 \text { - Argentina (Punta Rasa) } \\
\left(36^{\circ} 18^{\prime} \mathrm{S}, 56^{\circ} 46^{\prime} \mathrm{W}\right)\end{array}$} & G011704 & $16 / 01 / 2002$ & $>2$ \\
\hline & G008696 & $15 / 02 / 2012$ & 5 \\
\hline & G003966 ${ }^{6}$ & $14 / 02 / 1999$ & 5 \\
\hline & G011978 & $15 / 02 / 2012$ & 7 \\
\hline & G002698 6 & $11 / 11 / 2001$ & 8 \\
\hline & G011085 & $12 / 12 / 2013$ & $>16$ \\
\hline
\end{tabular}

${ }^{1}$ Found dead ${ }^{2}$ Birds captured alive by fisherman and released. ${ }^{3}$ From Lima et al. $2004{ }^{4}$ From Hays et al. $1999{ }^{5}$ Bird recovered in two different years ${ }^{6}$ From Neves et al. 2002 
Table S2: Common Terns Sterna hirundo ringed in Brazil during the wintering period and later recovered breeding in the Azores. Table presents data for ringing. Site number code corresponds to that shown in Fig 2.

\begin{tabular}{|cll|}
\hline Site & Ring & $\begin{array}{l}\text { Date of } \\
\text { ringing }\end{array}$ \\
\hline 3 - Brazil (Mangue Seco) & $\mathrm{H}-50217$ & $27 / 01 / 2003$ \\
$\left(11^{\circ} 27^{\prime}, 37^{\circ} 21^{\prime}\right)$ & $\mathrm{H}-50133^{1}$ & $27 / 01 / 2003$ \\
& $\mathrm{H}-35381^{2}$ & $28 / 12 / 1996$ \\
& $\mathrm{H}-69077$ & $11 / 02 / 2009$ \\
& $\mathrm{H}-55981$ & $24 / 11 / 2009$ \\
& $\mathrm{H}-56115$ & $16 / 11 / 2007$ \\
& $\mathrm{H}-40901^{1}$ & $24 / 02 / 2000$ \\
& $9822-16445^{1}$ & $18 / 02 / 1998$ \\
& $\mathrm{~J}-08146$ & $21 / 02 / 2002$ \\
\hline
\end{tabular}

${ }^{1}$ Found dead

${ }^{2}$ From Hays et al. 1999 


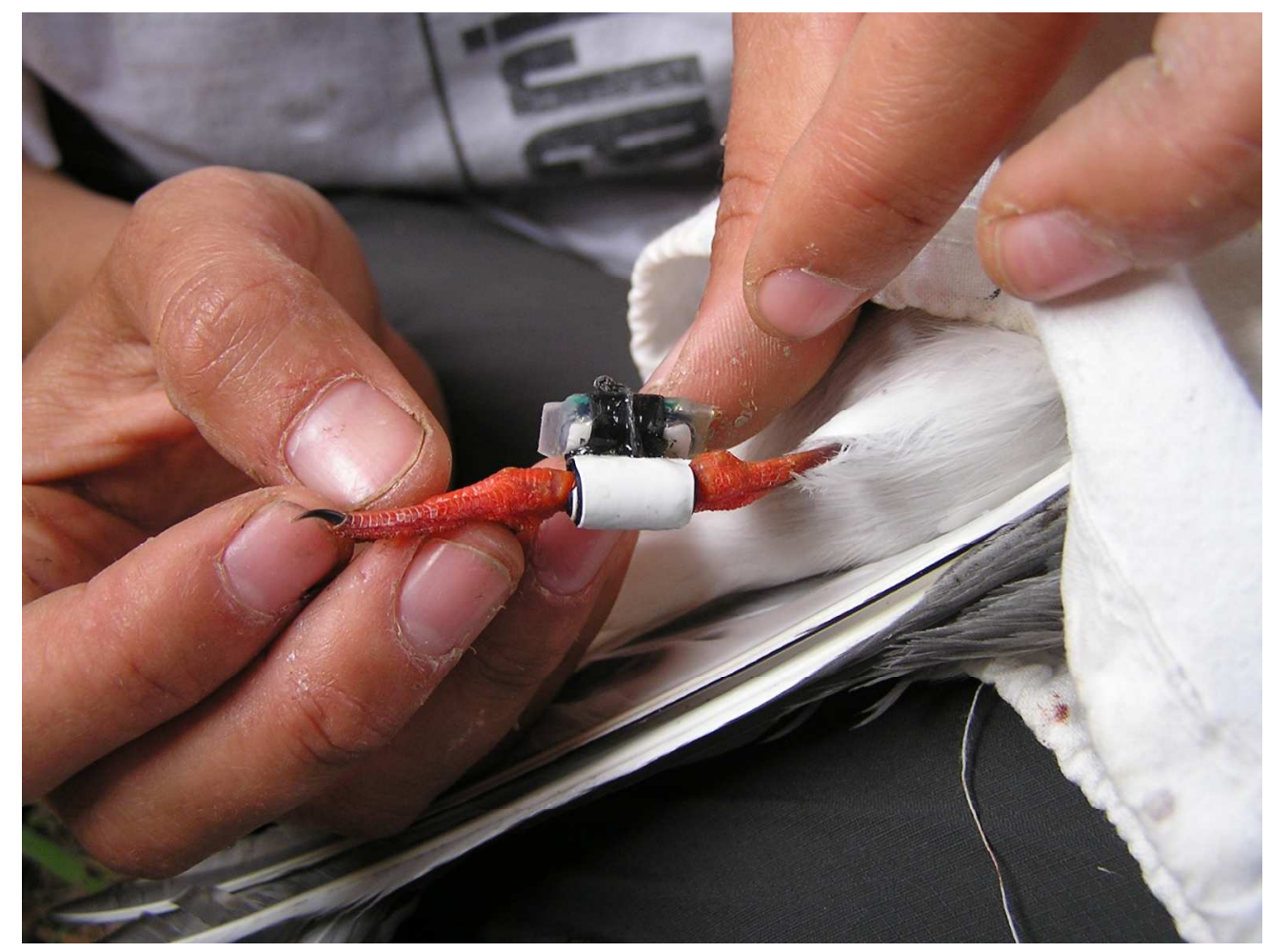

Figure S1: Leg of a Common Tern (Sterna hirundo) showing the Mk10 geolocator deployed on a darvic ring. $722 \times 541 \mathrm{~mm}(72 \times 72 \mathrm{DPI})$ 


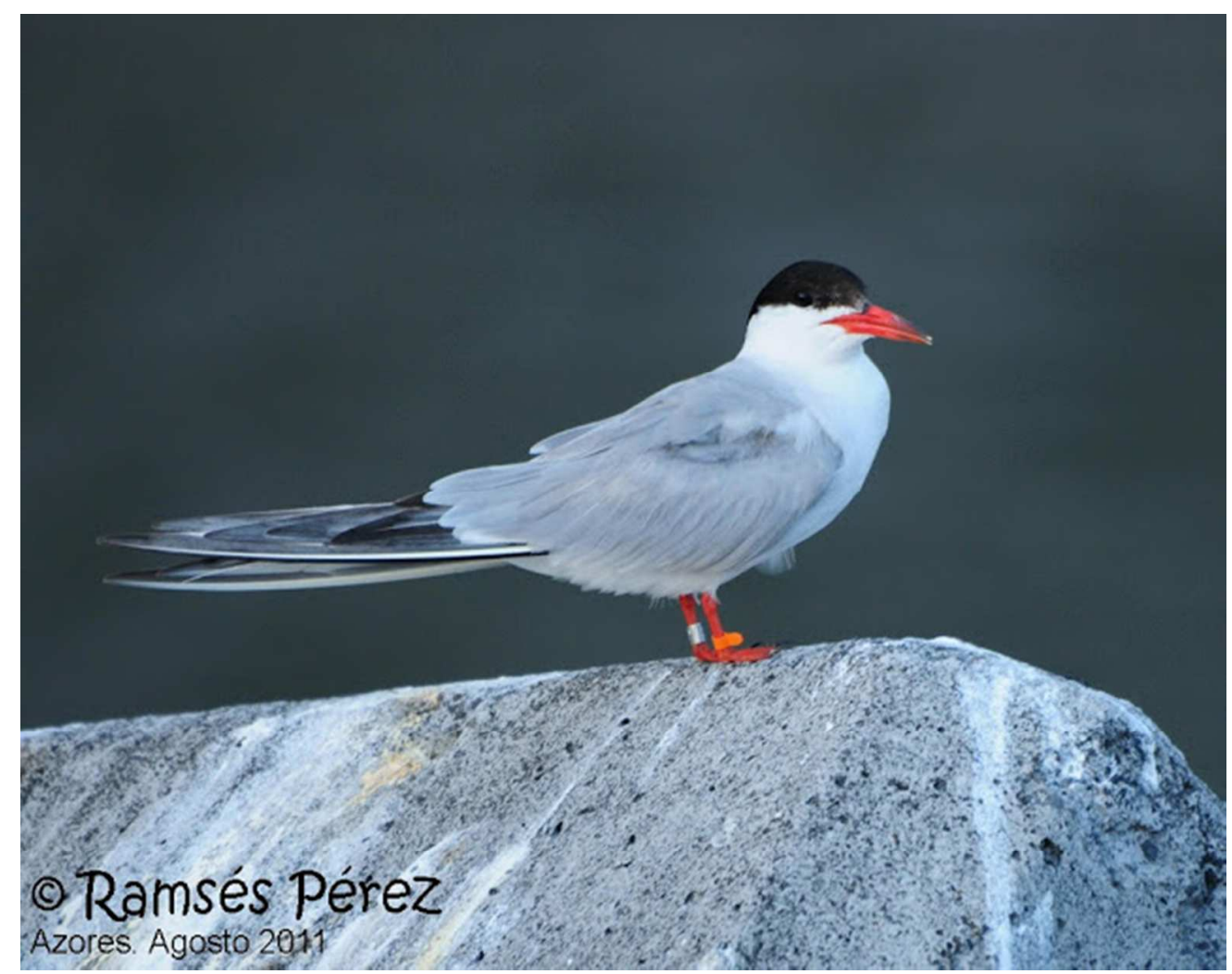

Figure S2: Picture of a Common Tern (Sterna hirundo) resighted in Lajes do Pico (Azores) in August 2011 and originally ringed in Punta Rasa (Argentina). (C) Ramsés Peréz. $225 \times 178 \mathrm{~mm}(72 \times 72 \mathrm{DPI})$ 